Cahiers $d u$ MONDE RUSSE

\section{Cahiers du monde russe}

Russie - Empire russe - Union soviétique et États indépendants

48/2-3 | 2007

Les résonances de 1905

\title{
Goroda i izbiratel'nyj zakon 1905 goda
}

\section{Ewa Bérard}

\section{OpenEdition \\ Journals}

Édition électronique

URL : https://journals.openedition.org/monderusse/9009

DOI : 10.4000/monderusse.9009

ISSN : $1777-5388$

Éditeur

Éditions de l'EHESS

Édition imprimée

Date de publication : 15 avril 2007

Pagination : 355-364

ISBN : 978-2-7132-2147-7

ISSN : $1252-6576$

\section{Référence électronique}

Ewa Bérard, « Goroda i izbiratel'nyj zakon 1905 goda », Cahiers du monde russe [En ligne], 48/2-3 |

2007, mis en ligne le 01 janvier 2007, consulté le 04 septembre 2022. URL : http://

journals.openedition.org/monderusse/9009; DOI : https://doi.org/10.4000/monderusse.9009 
chercher : repérer : avancer

Cet article est disponible en ligne à l'adresse :

http://www.cairn.info/article.php?ID REVUE=CMR\&ID NUMPUBLIE=CMR 482\&ID ARTICLE=CMR 4820355

Goroda i izbiratel' nyj zakon 1905 goda

par Ewa BÉRARD

Editions de I'EHESS | Cahiers du monde russe

2007/2-3 - Vol 48

ISSN 1252-6576 | ISBN 9782713221477 | pages 355 à 364

Pour citer cet article :

—BÉRARD E., Goroda i izbiratel’ nyj zakon 1905 goda, Cahiers du monde russe 2007/ 2-3, Vol 48, p. 355-364.

Distribution électronique Cairn pour les Editions de l'EHESS.

(C) Editions de l'EHESS. Tous droits réservés pour tous pays.

La reproduction ou représentation de cet article, notamment par photocopie, n'est autorisée que dans les limites des conditions générales d'utilisation du site ou, le cas échéant, des conditions générales de la licence souscrite par votre établissement. Toute autre reproduction ou représentation, en tout ou partie, sous quelque forme et de quelque manière que ce soit, est interdite sauf accord préalable et écrit de l'éditeur, en dehors des cas prévus par la législation en vigueur en France. Il est précisé que son stockage dans une base de données est également interdit. 


\section{EWA BÉRARD}

\section{ГОРОДА \\ И ИЗБИРАТЕЛЬНЫЙ ЗАКОН 1905 ГОДА}

В литературе о 1905 годе, город как самостоятельный общественный и исторический сюжет, упоминается редко. Обычно историки, как российские такизападные, объектомисследованиявыбираютлибоотдельныесоциальные классы, либо земства, партии и другие новосозданные политические институты. Развитие капиталистических отношений прослеживается то в рамках аграрного хозяйства, то в рамках промышленности. Город как таковой, где нарастающее движение среди буржуазии и рабочих сочетается с развитием гражданского общества и городской культуры, и, прежде всего, с независимым городским управлением, почти не рассматривается.

А между тем, зарождение городского либерализма в форме городских дум и профессиональных союзов, думская деятельность сменившая разложившийся государственный аппарат и, наконец, всеобщая политическая забастовка как новая форма гражданского сопротивления и первое выступление такого типа в европейской истории, свидетельствуют о незаурядной роли города.

Чтобы понять, какова была роль городов в «государственном переустройстве», можно исследовать такой показатель как закон о выборах в Государственную думу. Какое место отводится горожанам или, точнее, городским жителям, в различных проектах избирательного закона? Некоторые из этих проектов исходили от городских деятелей: носят ли они отпечаток своего происхождения? Можно ли в них выделить черты особого городского самосознания? Конституционное и революционное движение 1905 года добилось созыва законодательного совещания. Этот шаг, ограничивающий императорскую власть, которая отныне будет называться только «самодержавной», но уже не «неограниченной», был закреплен Манифестом 17 октября. Но одновременно происходил другой, не менее важный процесс: доктринарно и традиционно землевладельческая страна, 
которой еще в августе предлагали «крестьянскую» Думу, после всеобщей стачки и московского восстания, предоставила избирательное право жителям городов. Этот именно процесс будет рассматриваться в нашей статье.

Среди исследовательских работ современников, городской аспект революции 1905 года нашел самое полное отражение в коллективном труде меньшевистского уклона, изданном в 1909 году под редакцией Л. Мартова, Общественное движение в России в начале ХХого века. Городам здесь посвященна глава А. Ерманского, «Выступления городских самоуправлений. Съезды городских деятелей», и глава Ф. Дана, «Очерк политической эволюции буржуазных элементов городского населения» ${ }^{1}$. Особый вопрос представляет роль городских дум в ходе конституционных реформ и революционного движения. В силу сословной разобщенности городского общества, которая, хотя и в ослабленном виде, сохранилась до конца царского режима, думы никогда не стали для буржуазии, как писал Ф. Дан, «такими центрами политического самоопределения, какими были земства для землевладельцев и даже для части крестьян»². Сегодня позиция, занятая городскими думами Санкт-Петербурга и Москвы в 1905 году, изучается в работах историков В.А. Нардовой и Л.Ф. Писарьковой ${ }^{3}$.

Главные вехи развития конституционного движения и дебатов вокруг избирательного закона достаточно известны; здесь я попытаюсь истолковать более подробно лишь городскую тему.

В начале напомним, что еще в 1903 году в Санкт-Петербурге была проведена, впорядке исключения, реформагородскогосамоуправления.Ввиду полной невозможности управлять столичным хозяйством при существующей системе выборов в городскую думу, было решено увеличить численность «городского общества». В следствии «контр-реформы» городового положения произведенной в 1892 году, повышенный имущественный ценз оставил избирательное право за небольшой кучкой городских жителей. В Петербурге число избирателей сократилось с 21170 до 7 425, представляя собою 0,6 \% городского населения. Суть петербургской реформы 1903 года заключалась в распространении избирательного права на городских жителей, не располагающих недвижимым имуществом, объединненных в категории так называемых «квартиронанимателей»; речь шла исключительно о налогоплательщиках высшего разряда ${ }^{4}$. Группа «квартиронанимателей»

1. Л. Мартов, П. Маслов, А. Потресов (изд.), Общественное движение в России в начале ХХого века, СПб., 1910, т. 2; А. Ерманский, «Выступления городских самоуправлений. Съезды городских деятелей», с. 60-100 ; Ф. Дан, «Очерк политической эволюции буржуазных элементов городского населения», с. 101-145.

2. Дан, «Очерк политической эволюции...», с. 102.

3. В.А. Нардова, Самодержавие и городские думы в России в конце ХІХ-начале XX века, СПб., 1994 ; Л.Ф. Писарькова, Московская городская дума 1863-1917, М., 1998 ; В.А. Нардова, В.М. Кручковская, А.С. Сухорукова, Петербургская городская дума, 1846-1918, СПб., АН, 2005.

4. Нардова, Самодержавие.., гл. 4 ; Г.И. Шрейдер, Наше городское общественное управление, т. 1, СПб., 1902, с. 290-292. 
представляла собою средний слой чиновничества и либеральных профессий. Согласно С.Ю. Витте, который с 1899 года ратовал за эту меру, плательщики квартирного налога хотя и не исполняли критерия имущественного ценза, «являлись именотой группой городских обывателей, которые как подостатку, так и по образованию и роду занятий, представляются наиболее способными стать выше узких интересов отдельных слоев населения и оказать своими познаниями и опытом содействие к направлению городского хозяйства на тот путь, который обеспечает плодотворное его развитие» ${ }^{5}$. Включение этих слоев в «городское общество» и наделение их избирательным правом было огромным шагом вперед по пути демократизации органов самоуправления. В этом смысле петербургская реформа явилась прецедентом в преддверии предстоящей конституционной борьбы, именно сама реформа и новый избирательный закон, а не Петербургская дума как таковая. Избранная в 1903 году уже на новых началах и пополненая так называемыми «новодумцами», она не проявила особенной политической активности, а в ходе революционных событий оказалась более лояльной и подчиненной царской бюрократии, чем Московская, не говоря уже о губернских думах. Московская дума, под председателъством городского головы князя Голицына, отличилась еще в конце ноября 1904 года. По поводу обсуждения сметы 1905 года, группа из 82-х гласных внесла заявление, в котором указывалось на те ненормальные «правовые условия, в которые поставлены городская община и население города» при административном режиме и на «несоответствия правительственного режима тем условиям, при которых возможно правильное ведение и развитие городского хозяйства». Заявление кончалось призывом ввести «контроль общественных сил над законностью действий администарции» и демократические свободы ${ }^{6}$. Это было первое яркое, политическое выступление городской думы, первая ласточка наступающей бури. Вестник Европь не ошибся, подчеркивая: «Такой обмен мыслей между представителями городского населения звучит чем-то мало привычным для русского уха» 7 .

Как известно, одновременно с Высочайшим рескриптом от 18 февраля 1905 года на имя министра внутренних дел гофмейстера А.Г. Булыгина, сообщающим царское желание «призвать избранных от населения людей» к участию в обсуждении законодательских предложений, был издан указ, который предоставлял частным лицам и учреждениям возможность подавать

5. Комиссия под председательством тов. министра В.Д. кн. А.Д. Оболенского по вопросу о передаче государственного квартирного налога в пользу городов, 30 июля 1899, Дело Хозяйственного Департамента МВД, ч. 2, 22.06.1899-18.07.1903, РГИА (Российский государственный исторический архив), ф. 1287, оп. 28, д. 496, л. 2. Документ приводится в книге: Saint-Pétersbourg : Nicolas II et les forces urbaines, подготовляемой к печати автором статьи.

6. Ерманский, «Выступления городских самоуправлений...», с. 63 ; Писарькова, Московская городская дума..., с. 246-248.

7. Вестник Европь, 1905 , кн. 1, с. 452. 
предложения о государственных реформах ${ }^{8}$ Этот указ открыл простор для свободного слова и собраний. Думы и биржевые общества стали ходатайствовать о допущении их представителей в новое совещание. Петербургская дума ответила благодарственным адресом, в то время как Московская и большинство губернских дум поддержали лозунги ноябрьского земского съезда требующие созыва не «народного», а «законодательного» представительства ${ }^{9}$. По всей стране началось обсуждение различных проектов конституции и избирательных законов.

Уже в конце февраля 1905 года в Москве состоялась первая в русской истории встреча городских голов. Напомним, что органам самоуправления запрещалось входить в горизонтальные отношения для обсуждения дел общегосударственного масштаба, и что думцы никогда не решались обойти этот запрет, как это делали земцы. На февральском съезде, городские головы благосклонно отнеслись к проекту Булыгинского совещания, требуя при том гласности дебатов ${ }^{10}$.

В мае 1905 году, на фоне радикализации общественных настроений вызванной Цусимским поражением, промышленники подают записку составленную от имени «всего промышленного сословия». В записке, наряду с лозунгом законодательного, а не законосовещательного собрания, указывается на необходимость признать избирательные права «... за классом фабричных и горных рабочих» ${ }^{11}$. Это важный момент: рабочий вопрос, как основной пункт «политической вольности», был выдвинут по почину промышленников. В записке промышленники напоминают, что согласно земскому Положению 1864 года, которое легло в основу булыгинского проекта, класс фабричных и горных рабочих лишен участия в выборах, а административное районирование лишает возможностей выбора в совещание и представителей промышленников. Напомним, что рабочие фабрик и заводов не числились среди «городских обывателей», по паспорту и по имущественному цензу были заведомо из городской жизни исключены, и вопрос об изменении этого положения до осенних стачек городскими деятелями не рассматривался. В мае делегаты земско-городского съезда откажутся даже принять депутацию промышленников. ${ }^{12}$ Да и позже, вопрос прав и свобод для рабочих будет ими обсуждаться только в бытовом аспекте, как забота о «положении рабочего класса» ${ }^{13}$.

6 июня 1905 года в Петергофе состоялась историческая встреча царя с делегацией земцев-конституционалистов и думцев, руководимой князем

8. С.С. Ольденбург, Царствование Императора Николая II, Ростов н/Д., 1998, с. 226 ; И.В. Гессен, « В двух веках, Жизненный отчет », Архив русской революции, Берлин, 1937, с. 196.

9. Нардова, Самодержавие..., с. 147; Дан, «Очерк политической эволюции...», c. 107.

10. Вестник Европь, 1905, кн. 4, с.795.

11. С.Е. Сеф, Буржуазия в 1905 году : По неизданным архивным материалам, M.-Л., 1926, с. 33, 118.

12. Сеф, Буржуазия в 1905 году..., с. 58.

13. K вопросу о думской помощи пострадавшим петербургским рабочим, см. В.А. Нардова, « Столичная дума в годы первой российской революции 19051907 », Петербургская историческая школа, т. 3, с. 246-265. 
С.Н. Трубецким. Впервые царь принял опальных руководителей общественного движения, впервые оппозиционная решимость земцев-конституционалистов захватила и горожан. Делегация выдвинула перед государем предложение всеобего, равного, без различия сословий, избирательного закона. А.Н. Никитин, заместитель председателя Петербургской думы, выступающий после князя Трубецкого, подчеркнул необходимость «начать культурную работу» ввиду предстоящих перемен, к которой надо будет призвать и «даровитых» городских людей ${ }^{14}$. Вскоре после этой встречи стали появляться в печати сведения о проекте Положения о выборах народных представителей от земств и городов, подготовленном правительственной комиссией. Термин «Земский собор», который выдвигался с осени 1904, был отброшен в пользу «Представительного собрания». Думцы же станут говорить о «совместном с монархом строительстве земли», [подчеркнуто Е.Б.] символически совмещая в двух последних словах понятия города и земства ${ }^{15}$.

15-16 июня, в Москве собирается съезд городских деятелей ${ }^{16}$. И этот съезд является беспрецедентным в истории русских городов. Из 205 приглашенных городских деятелей съехалось 117. Думцы заметно радикализируются: они отвергают булыгинский проект, составленный «негласным канцелярским порядком», принимают формулу всеобщих, равных, тайных и двухстепенных выборов. Иначе говоря, они становятся на позицию земцев и промышленников. Так, например, в заключительном документе съезда указывается на необходимость объединения общегородской организации с общеземской. Но намечаются и различия, и на эти различия я бы хотела обратить внимание:

Во-первых, отметим культурный и бытовой штрих: съезд выдвигает требование избирательных прав для женщин ${ }^{17}$. Городские представители оказались единственной группой, которая пошла на этот шаг безоговорочно. Двумя годами раньше, когда Петербург ликовал по поводу городской реформы и новых избирательных прав в органы самоуправления, газета Петербургский листок поместила на первой странице рисунок представляющий элегантную даму, с очаровательной улыбкой решительно пересекающую зал выборного участка по направлению к урне ${ }^{18}$. Эмансипация женщины стала прочной чертой городской культуры. Когда 6 июня 1905 года московские промышленники и железнодорожники проголосуют за всеобщую, равную, двухстепенную подачу голосов, они сочтут невозможным, «в виду установившегося взгляда на женщину в деревне», распространить

14. Известия Петербургской городской думьь, 1905, № 24, с. 756 ; Вестник Европьь, 1905, кн. 7, с. 335.

15. Дан, «Очерк политической эволюции...», с. 112.

16. Ерманский, «Выступления городских самоуправлений...», с. 66 ; Дан, «Очерк политической эволюции...», с. 112.

17. Сеф, Буржуазия в 1905 году..., с. 47.

18. « На выборах », Петербургский листок, 2(15).12.1903, № 331. 
это право на женский пол ${ }^{19}$. Делегаты земско-городского съезда, который в эти же дни заседал в Москве, «вполне признавая желательным политическое равоноправие женщин», также сочтут несвоевременным и «непрактичным затруднять учредительский момент слишком сложными требованиями» ${ }^{20}$. Этот пункт будет отклонен даже на учредительном съезде кадетской партии в октябре 1905 года ${ }^{21}$.

Во-вторых, требования представителей городов отличаются от программы земцев и промышленников и в чисто политическом аспекте. А именно, съезд проголосовал за предоставление городам особенных избирательных льгот: предлагалось, чтобы переделы городских избирательных округов были вдвое меньше, чем сельских. Иначе говоря, устанавливалось соотношение голосов один к двум в пользу городов. Интересно, что в ходе дискуссий первоначальное предложение заметно радикализировалось. Подготовительный проект московской коммиссии предусматривал льготы только крупным городам (с населением не меньше пятидесяти тысяч ), объясняя это тем, что в них «сосредоточены громадные торгово-промышленные интересы и почти все, что в России есть наиболее культурного». Съезд пошел дальше этого проекта и решил распространить предлагаемую систему на все города ${ }^{22}$.

Принимая во внимание ведущую роль земств и всепоглощающий крестьянский вопрос, дерзость городских требований нуждается в комментариях. Федор Дан объясняет эту вспышку городской самоуверенности, с одной стороны, антагонизмом между крупными городами и земством по поводу вопроса о земском обложении и выделении городов в «самостоятельные земские единицы», вопрос, который будет поставлен со всей силой после 1905 года, по мере роста значения городов. С другой стороны, Дан указывает на известный «страх земского либерализма» (чьи представители являлись нередко и городскими гласными и заседали в городских думах) перед «деревенской некультурностью». Выдвинув лозунг всеобщего избирательного права, либералы, как земские так и городские, вдруг отдали себе отчет в том, что голосующее крестьянство вряд ли окажется надежным союзником; для земской интеллигенции и земских деятелей на заре ХХого века, именно города оказались оплотом правовых реформ. В требовании городских льгот отчетливо выразилось осуждение неграмотности крестянства, причем, пожалуй, впервые эта культурная отчужденность получила политическое оформление.

6 июля в Москве собирается первый совместный земско-городской съезд. На 140 представителей земств приходит 84 представителя городов. Комментируя весомость городского представительства советский историк двадцатых годов С.Е. Сеф, пишет: «Только сродством политических интересов земств и городов, а не подчинением городов земской гегемонии

19. Сеф, Буржуазия в 1905 году..., с. 57.

20. Там же, с. 62.

21. Гессен, « В двух веках...», с. 205.

22. Дан, «Очерк политической эволюции...», с. 113-114. 
можно объяснить это единство движения» 23 .

Итак, назревающий экономический и политический конфликт между земством и городскими думами перерождается в «сродство интересов», когда речь идет о раскрепощении местного самоуправления, эманципации по отношению к центральному аппарату самодержавия. Единственной силой, которая будет решительно отстаивать Положение 1864 года, регулирующее отношения между городом и землевладением, оказывается царская власть.

6 августа 1905 года был обнародован бульгинский проект Государственной думы, подтверждающий совещательный характер будущего народного представительства ${ }^{24}$. Созыв совещания был назначен на февраль 1906 года. В основу избирательного закона, сопровождающего проект, легло, после бурных дебатов, Положение о земских учреждениях 1864 года. Закон был всецело подчинен идее землевладельческой Думы. Избирательные права (право участия в избирательном собрании выборщиков, которые впоследствии избирали депутатов в Думу) признавались почти за всеми волостными крестьянами и землевладельцами, в то время как в городской курии избирательным правом пользовались только лишь домовладельцы и крупные плательщики торгового, промышленного и квартирного налога. Рабочие, чиновники, либеральные профессии и интеллигенты - т.е. большинство городского населения - были почти совершенно исключены. Только двадцать больших городов центральной России (на 51 губернских округов) с населением больше 100000 получили статус самостоятельных избирательных округов, а следовательно, и право устраивать особые предвыборные собрания ${ }^{25}$. Выборщики от других городов выбирали депутатов на губернских избирательных съездах. В Петербурге, на полтора миллиона жителей, избирательное право получили 9500 человек. Всего города получили право послать в будущую Государственную думу 28 из 412 депутатов ${ }^{26}$.

«Слишком поздно, слишком слабо, чтобы успокоить страну», писал Вестник Eвропь по поводу булыгинского закона ${ }^{27}$. Лозунг бойкота выборов в Думу оказался весьма популярен среди членов Союза Освобождения и Союза Союзов, где считали, что булыгинский избирательный закон обеспечивает правительству «покорное» крестьянское большинство 28 . Земский же съезд, который заседал уже в легальных условиях в Москве 13-15 сентября 1905 года отклонил лозунг бойкота Думы, но проголосовал за расширение прав народного представительства и всеобщее голосование.

23. Сеф, Буржуазия в 1905 году.., с. 48.

24. Н.И. Лазаревский, Законодательные акты переходного времени, 19041908, СПб, 3 изд., 1909, с. 98, 115. См. также Р.ШІ Ганелин, Российское самодержавие в 1905 году : Рефбормы и революция, СПб., 1991, с. 168-172.

25. Marc Szeftel, «The legislation Reform of August 6, 1905 (the "Bulygin Duma")», Mélanges Antonio Marongiu, Études présentées à la Commission Internationale pour l'Histoire des Assemblées d'États, Palermo, 1967, p. 137-184 ; p. 177.

26. Дан, «Очерк политической эволюции...», с. 117

27. Вестник Европьь , 1905, кн. 9-10, с. 354.

28. Ольденбург, Царствование Императора..., с. 253. 
10 октября в Москве была объявлена всеобщая забастовка. Почти одновременно Николаю II были представлены три проекта манифеста, составленные графом Витте, И.Л. Горемыкиным и князем А.Д. Оболенским, все три предлагали дарование гражданских свобод и расширение избирательных прав. Манифест был обнародован 17 октября. Он объявлял срочный созыв Годусдарственной думы и уточнял: «Не останавливая назначенных выборов, привлечь теперь же к участию в Думе $<\ldots>$ те классы населения, которые ныне совсем лишены избирательных прав $<\ldots>{ }^{29}$. Ввиду назначенного срока созыва (февраль), надо было «менять на ходу», как выразился Витте, избирательный закон ${ }^{30}$. Требуемое земцами всеобее избирательное право было отклонено, как слишком радикальное.

11 декабря, в разгар московского восстания, был издан указ о порядке выборов в Государственную думу. Было решено сохранить булыгинскую систему опосредованных и неравных выборов, но с сильно пониженным цензом. Благодаря понижению ценза и введению новых категорий выборщиков, все три курии - землевладельческая, крестьянская и городская - стали гораздо более демократичными. Как требовали промышленники, была установлена рабочая курия, вне критерия имущественного ценза. Только двадцать больших городов центральной России (и шесть на окраинах) получили статус самостоятельных избирательных округов ${ }^{31}$.

Современники и историки по разному оценивают значение указа 11 декабря 1905 года: хотя новый избирательный закон являлся несомненной уступкой городскому движению, он все еще не обеспечивал городским силам надлежащего представительства в будущей Думе ${ }^{32}$. Указывая, что закон расширил число городских избирателей, Вестник Европь тем не менее заключал: «Но вообще определится состав Думы не представителями городов. Во-первых, города только по исключению будут иметь особых

29. Лазаревский, Законодательные актыл.., с. 178.

30. Приглашенные на совещание в Петергоф, 5, 7 и 9 декабря, делегаты земцев выступили с предложением всеобщего избирательного права; это предложение было отклонено как слишком радикальное.

31. Интересно заметить, что в этих-то округах впервые была применена современная, одностепенная система выборов, без посредничества «выборщиков» и при помощи печатных бюллетеней а не шариков. См. Emmons, «Russia's First National Elections»; F-X. Coquin, C. Gervais, 1905 : La première révolution russe, P. : Institut d'Études slaves, Collection historique, 1986, p. 35.

32. Дан, «Очерк политической эволюции...», с. 129; Н. Череванин, «Движение интеллигенции», Л. Мартов, П. Маслов, А. Потресов (изд.), Общественное движение в России..., с. 194. Марк Шефтель, крупный историк русского конституционного права, напоминает, что новый закон увеличил число городских избирателей с 18000 до 3500000 и подчеркивает его демократичный и универсальный характер. Тем не менее, считает Шефтель, система курий и неравных избирательских округов обеспечивала перевес аграрных депутатов. Демократический же характер нового указа будет сведен на нет законом 3 июня 1907. Marc Szeftel, «Le Manifeste du 17 octobre et son rôle dans l'évolution constitutionnelle de l'empire », Coquin, Gervais, 1905 : La première révolution russe..., p. 20. 
представителей; в большинстве же, выборщики от городов расплываются в преобладающих и чужих им группах от землевладельцев и крестьян.» ${ }^{33}$

Процитируем два распоряжения указа, касающиеся городов, или, точнее, непролетарского городского населения:

Первое распоряжение касается собственно городского населения: получают избирательное право «средние и низшие разряды городского населения, черпающие средства к жизни отчасти в умственном труде, отчасти в торговле и промыслах», иначе говоря, снижается имущественный и налоговый ценз ${ }^{34}$. Предоставлено избирательное право всем частным и государственным служащим, а также и всем квартиронанимателям. Согласно Bестнику Eвропь, число избирателей в самом Петербурге увеличилось в 20 pas $^{35}$.

Но другое распоряжение имеет в виду внегородское население, а именно: привлекается к выборам «весь обширный класс лиц, проживающих вне городов и получающих содержание или пенсию по службе государственной, земской, сословной и на железных дорогах» ${ }^{36}$. Все они зачисляются указом в «городские обыватели», иначе говоря, в городскую курию. Решение это объясняется законодателем тем, что вышеупомянутые лица «по существу своих интересов, представляют городской класс населения и не имеют той связи с землевладением, которая могла бы обеспечить им возможность приобрести здесь какое-либо влияние на исход выборов, тогда как в городах, объединяясь с однородными общественными элементами, лица эти могут и сами быть избранными и провести в Думу своих представителей».

Смысл этого распоряжения не совсем ясен. Как истолковать причисление к городской курии «третьего элемента» земств и железнодорожников, заведомо наиболее радикальных слоев общества? Надо ли понимать, что главной заботой Николая II оставалось все же сохранить нерушимым крестьянское ядро будущей Государственной думы? Оградить деревню от влияния разлагающих интеллигентских и рабочих элементов? Обострить разобщение городского общества, включив в его состав новые категории избирателей?

Итак, дебаты, которые велись на протяжении 1905 года от июньского городского съезда вплоть до указа 11 декабря вокруг избирательного закона, свидетельствуют не только об эволюции конституционного замысла. По ним можно проследить и историю городов: рост городского самосознания, становление политической мощи городских центров, меняющееся соотноше-

33. Вестник Европь, 1906, кн. 3-4, с. 430.

34. Текст распоряжений цитируется по публикации «Правительственное разъяснение к избирательному закону 11 декабря 1905 », Известия Петербургской городской думы, 1905, № 33, с. 1642-1647. Так как речь шла лишь о «разъяснениях» к закону 6 Августа 1905, текст Высочайшего указа 11 декабря 1905 не фигурирует в сборнике Лазаревского, Законодательныле акты...

35. Вестник Европь, 1906, кн. 3-4, с. 430.

36. Известия Петербургской городской думы, 1905, № 33. 
ние сил между городом и деревней, между бывшим, сословным «городским обществом», как оно определялось Положением 1870, года и новой действительностью риссийских метрополий.

Победа депутатов Конституционно-демократической партии на выборах в Государственную думу решалась в большой степени в городах. Как пишет Федор Дан: «Разбитые в открытом бою и не успевшие отдать себе отчета в размерах поражения, <массы городского населения> пытались новым способом, новой концентрацией сил - на этот раз вокруг Думы - добиться реализации тех прав, которые формально числились за ними» ${ }^{37}$. Из 115 депутатов, посланных городским населением выборщиками в Государственную Думу, не менее 95 принадлежали к оппозиции, а из этого числа подавляющее большинство (83), принадлежало к кадетской партии ${ }^{38}$. Насколько важен был городской вопрос, и насколько неполное решение получил он в 1905 году, показывают послереволюционные годы. Сразу после выборов в Государственную думу, доминирующая кадетская фракция выступила с проектом всероссийской реформы городского положения ${ }^{39}$. Такого же рода проект разрабатывался одновременно министерством внутренных дел. Но городская реформа, как мы знаем, так и не будет осуществлена. В 1909 году, в Государственной думе формируется, по инициативе Л.А. Велихова, внепартийная городская фракция. Л.А. Велихов являлся также и основателем журнала Городское дело. В 1913 году, после того, как правительством был запрещен всероссийский съезд городов, Велихов писал:

«Особый толчок к росту городов дало наше общественное движение 1904-05 годов. <..> В патриархально-дворянском укладе жизни впервые образовалась брешь. <...> Старинная формула: "Россия есть и будет страной землевладельческой” становится все менее и менее верною. <..> Из всех недорозумений, происходящих в государственной жизни России, законодательное и правительственное пренебрежение к нуждам городов может быть наиболее серьезно и чревато последствиями.» ${ }^{40}$

\section{CNRS, UMR 8547 Transferts culturels}

ewa.berard@ens.fr

37. Дан, «Очерк политической эволюции...», с. 129-130.

38. Н.А. Бородин, Государственная Дума в цифрах, СПб, 1906. См. также Emmons, «Russia's First National Elections...», p. 39.

39. М. Щепкин, « Основы городовой реформы », Самоуправление, 1907, № 5 , № 6 , № 7 .

40. Л.А. Велихов, « Муниципальное обозрение », Городское дело, 1913, № 2. 